Article

\title{
Sustainable Literary Competence: Connecting Literature Education to Education for Sustainability
}

\author{
Per Esben Myren-Svelstad \\ Department of Teacher Education, Faculty of Social and Educational Sciences, \\ Norwegian University of Science and Technology, NO-7491 Trondheim, Norway; per.svelstad@ntnu.no
}

Received: 30 October 2020; Accepted: 2 December 2020; Published: 3 December 2020

\begin{abstract}
Ecocritical scholarship has always had pedagogical ambitions. It is commonly assumed that education based on ecocritical readings of literature will change the attitudes and actions of pupils and students and thus contribute to forming environmentally aware and sustainable citizens. However, this article proposes an alternative view on the interaction between sustainability and literature education. Based on a critical discussion of "ecocritical orthodoxy," this meta-theoretical study uses affect theory in conjunction with Rita Felski's proposal for postcritical reading to argue that literature education needs to take the polysemy of literary texts and the unpredictability of readers' encounters with such texts into account. By linking this to a specified set of sustainability competences and a dialogic concept of literary competence, the aim of the main discussion is to highlight the many potentially fertile overlaps between literature education and the competences needed in a sustainable citizen. Here, Timothy Clark's thoughts on the Anthropocene as threshold concept, and Timothy Clark's views on irony are important parts of the theoretical framework. Moreover, such a framework for sustainable literary competence could help to argue for the value of literature education and genuine literary competence.
\end{abstract}

Keywords: literature education; education for sustainability; literary competence; postcritical theory; affect theory; literary ethics; the ecological thought

\section{Introduction}

A common assumption in ecocriticism is that reading literary texts shapes the reader's beliefs and attitudes. Reading novels, plays, and poems that depict an ecocentric worldview is regarded as supporting the transition to a sustainable society: literature provides us with deep and rich accounts of the non-human, teaching us environmentally friendly attitudes in ways in which other texts and media do not. From a pedagogical point of view, this idea is often used to argue that children can become "ecocitizens" through literature education (cf. Massey and Bradford 2011). However, as British ecocritic Timothy Clark argues, the idea that "knowledge of interconnection must somehow lead to an ethic of care" can only with difficulty be defended from the perspective of the Anthropocene (Clark 2015, p. 189). Moreover, while theories of the ethical effects of reading literature, especially narrative fiction, abound (cf. Hale 2007), several scholars are critical of what they perceive as facile linkages between literary reading and ethical behavior (Keen 2010; Serpell 2014). In short, there is a need for a more fundamental theoretical discussion of the relations between literature, literary ethics, and education for sustainability (ES). The aim of this article is to contribute to such a discussion.

I choose the term education for sustainability instead of competing concepts like environmental education (EE) or ecocritical pedagogy. Historically, EE has focused on problems of the environment, placing less emphasis on the interplay between the non-human physical world and human society, or the role that human culture plays for a sustainable society (cf. McKeown and Hopkins 2003, pp. 118-19). Education, however, is arguably all about interaction between humans and how humans 
relate to the "social" and "natural" lifeworld. This is also a core concern of sustainability, following the definition offered by the Brundtland commission as development that "meets the needs of the present without compromising the ability of future generations to meet their own needs" (Report of the World Commision on Environment and Development: Our Common Future 1987, p. 16). Ecocritical pedagogy has traditionally been closer to EE than ES. As Greg Garrard argues, one of the reasons for this is the fascination with wilderness that characterized the "first-wave" ecocriticism of the 1990s (Garrard 2007, p. 363). The choice of ES in the following discussion is thus partly motivated by a wish to distance it from what is arguably a romanticized and uncritical view of "nature," and the analogous "pious form of ecocriticism" (ibid., p. 365). Moreover, as I argue in Section 5, sustainability provides a more defined set of competences that allows us to perceive the possible links between ES and the literary competence that schools and colleges should aim at fostering. I therefore call the theoretical framework developed below sustainable literary competence.

The specific motivation for the following discussion is my background in teacher education in Norway, where sustainable development is one of three interdisciplinary topics to be addressed in all school subjects from 2020 onwards (Utdanningsdirektoratet 2019). However, while briefly referring to topical issues in Scandinavian L1 scholarship, the theoretical discussion mainly deals with general questions and problems in international literary and ecocritical scholarship. Moreover, the concluding assertion of the article is that sustainability can be a foundation for highlighting the value of literary studies, which can offer a useful line of reasoning for all teachers of literature.

In the following, I will first present and discuss the problems with what I call "the altruistic paradigm of ecocritical pedagogy." I then turn to an account of postcritique and affective hermeneutics (Felski 2015) to discuss the relevance of these theories of reading and interpretation for a sustainable literary competence. Further, I describe how a literary ethics based on undecidability, darkness, and risk (Lesnick 2006; Morton 2007, 2012; Serpell 2014) makes salient the connections between literary ethics and ecological thought (Morton 2010,2012). This in turn forms the basis for identifying important points of connection between literary competence and the desired competences of a sustainable citizen. Finally, I outline what a literary-ecological classroom might look like if the theoretical framework is implemented through dialogic teaching (Mercer 2000; Blau 2003) and radical aesthetics (Armstrong 2000; Thavenius 2004). The main objective of the article is to explore the following question: What are the pedagogically useful links between imaginative literature, literary competence, and ecological thinking?

\section{The Problem with the Altruistic Paradigm of Ecocritical Pedagogy}

In What is literature?, Jean-Paul Sartre offers a suggestive definition of what characterizes the literary text compared to other uses of language. "[I]n each word," writes Sartre, the poet "realizes, solely by the effect of the poetic attitude, the metaphors which Picasso dreamed of when he wanted to do a matchbox which was completely a bat without ceasing to be a matchbox" (Sartre 1988, p. 31). This is a striking description of the polysemy of literary texts. Any content word has a denotation, but also an array of connotations actualized by its placement in the text, by intertextual references, or by the reader's personal associations. However, the myriad connotations of a word are allowed to remain true at the same time. The matchbox might connote a bat to me, while it simply connotes a matchbox to you — and both meanings may be justified.

While Sartre is only one of many to highlight polysemy as a defining element of literary texts (cf. Barthes 1970; Iser 1984; Felski 2008), one could claim that there has been a tendency in ecocriticism to isolate particular textual messages and argue that the unique value of literature is its capacity to influence readers. Hannes Bergthaller describes what he calls "ecocritical orthodoxy" in this way: "The idea that the roots of the ecological crisis are to be found in a failure of the imagination, and that literary studies-the human imagination being their home turf-therefore have an important role to play in understanding and overcoming this crisis" (Bergthaller 2010, p. 730). Carrying out literary analysis on the basis of such an idea arguably makes only one textual message valuable: "humans 
ought to acknowledge (to properly perceive) that they are a part of nature and behave accordingly" (ibid., p. 731). There are three main problems with this.

First, ecocritical orthodoxy risks producing a reductive view of imaginative literature. This downplaying of polysemy also contradicts the importance, so often emphasized in scholarship on literature education, of using challenging texts and open, dialogic approaches (cf. Blau 2003; Sønneland 2019). I return to this issue in greater detail in the following sections.

A second problem with ecocritical orthodoxy stems from the fact that using imaginative literature as a way of relaying information on the environment seems to rest on an "information deficit model" of environmental action. Such models, assuming that knowledge of the environment and global warming forms the basis of environmental action, are now broadly considered insufficient (Burgess et al. 1998, p. 1147; Kollmuss and Agyeman 2002, p. 241). As environmental governance researcher Susan Owens underlines, "[a] substantial body of social-scientific research suggests that, while greater knowledge may be worthwhile in its own right, barriers to action do not lie primarily in a lack of information or understanding" (Owens 2000, p. 1143). Furthermore, political scientists Anja Kollmuss and Julian Agyeman note that not only knowledge but even attitudes towards the environment "have been found to have a varying, usually very small impact on pro-environmental behavior" (ibid., p. 252). This indicates that even altruistic attitudes on climate action are insufficient to promote sustainable development. Thus, even if readers did develop knowledge of, and caring attitudes towards, the environment by reading literature, it is not obvious that this would lead to more sustainable practices in the real world.

Arguably, the models of "information deficit" and altruism undergirding ecocritical orthodoxy are closely connected to a tendency in literary scholarship and literature education to justify literary studies by their supposed ethical effects. Arguably, the most prolific spokesperson for this view is American philosopher, legal scholar, and classicist, Martha Nussbaum, who argues that narrative fiction has a special potential for immersing readers in the experiences and problems of those different from oneself. Reading powerful and troubling accounts of the lives of, e.g., ethnic and sexual minorities, can contribute to fostering world citizens: "Narrative art has the power to make us see the lives of the different with more than a casual tourist's interest—with involvement and sympathetic understanding, with anger at our society's refusals of visibility" (Nussbaum 1997, p. 87). Granted, Nussbaum highlights the importance of the teacher; books do not arouse sympathy by themselves but may influence attitudes and perceptions through conscious pedagogical effort (ibid., p. 41). She also makes allowance for the polysemy of literature and the unpredictability of students' responses (ibid., p. 99). Still, her ideas are often invoked to argue that literature education is important because it can make us into more empathetic and ethically aware human beings.

Empirical evidence for this "empathy-altruism" hypothesis, however, is "not robust," writes Suzanne Keen (2010, p. 167) in a thorough critical discussion of this hypothesis. One important reason is that in reading literature, there is no expectancy of reciprocation: where empathic-altruistic behavior in the physical world is often motivated by the belief that the other person might help me in the future, I have no reason to expect such reciprocity from characters in a novel (ibid., pp. 15-6). Similarly, indirect experiences of the environment, such as learning about environmental problems in school, are much less strongly correlated with pro-environmental behavior than are direct experiences of environmental problems (Kollmuss and Agyeman 2002, p. 242). Moreover, the polysemy of literature also blocks any simple link between reading and particular attitudes towards other people, as Keen underlines: "Readers accustomed to discussing their reactions to books with others will recognize the phenomenon of being surprised by the ways other readers feel about, or judge, negatively portrayed figures" (Keen 2010, p. 75). Results from the nascent field of empirical ecocriticism demonstrate this point. As, e.g., Matthew Schneider-Mayerson (2018, p. 484) has shown, some readers of climate fiction even reject the depictions of dystopian futures in such novels as exaggerated and thus untrustworthy. In short, the empathy-altruism hypothesis is not attentive enough to the unpredictability in reactions 
of readers. I regard ecocritical orthodoxy as a specific example of this hypothesis and would therefore argue that it could more specifically be called the "altruistic paradigm of ecocritical pedagogy."

The third and final problem with this paradigm is the fact that the laudable aims of caring for the environment and contributing to a more sustainable future are rather vaguely defined targets. Indeed, the idea of sustainability itself is a strongly contested and multifaceted term (Garrard 2007, p. 359). Owens points out how the concept's initial success was due to its ability to reconcile the goal of environmental conservation with the need for further material growth. As such, it somehow promised to "meet everyone's requirements" and enjoyed a remarkable discursive proliferation (Owens 2003, p. 6). But precisely this openness has proved to offer a challenge in implementing sustainable development, as it entails conflicting ethical and political decisions (ibid., p. 7). Therefore, it is not obvious how this idea can or should be implemented in literature education. A sustainable literary competence would thus need to operate with a clearly defined understanding of what sustainability consists of, and how reading and teaching literature relates to that concept. Indeed, the very indeterminacy of the concept could offer an opportunity to isolate how specific aspects of sustainability connect to literary reading.

All this should lead to a fundamental skepticism towards the idea that literature should play an important, if not the most important, part in countering climate change. That is not, however, to say that literature can play no part. It only implies that we owe it to the magnitude of the problem of climate change and the complexity of literary reading to consider what exactly the relation between literature and sustainability might be.

Sangfroid with respect to the beneficial effects of literary reading is no less important at a time when the experience of the Anthropocene fundamentally questions the notion that there is such a thing as a human who can take specific actions to produce a sustainable outcome. Clark (2015) fleshes out the problem more fully by exploring the Anthropocene as what he calls a "threshold concept": "As a concept transferred from geology, the Anthropocene enacts the demand to think of human life at much broader scales of space and time, something which alters significantly the way that many once familiar issues appear" (Clark 2015, p. 13). The lives of humans and non-humans are now linked together in ways that preclude a full overview; systemic risks in a globalized world call for new strategies of management (cf. Goldin and Mariathasan 2014). To give a prosaic example: what seems environmentally friendly on a local level, such as recycling the plastic wrapping my food came in, might have environmentally detrimental effects on a global level, if the waste to be recycled needs to be transported over vast distances.

However, acknowledging these problems does not deny all value to traditional ecocritical readings. Critical studies of how categories such as "the human," "the environment," or "nature" are perceived, depicted, and constructed in literary texts are surely important. Traditional ecocritical studies of literature contribute to knowledge of the relationship between humans and the environment, and while information deficit models are inadequate, knowledge still plays a crucial role in solving environmental problems (cf. Owens 2000, p. 1144). Likewise, efforts to empirically investigate how and to what extent environmental literature influences its readers is no doubt a much-needed addition to ecocriticism (cf. Schneider-Mayerson et al. 2020). However, the above criticisms of the altruistic paradigm question just how useful altruistic versions of ecocriticism can be in implementing sustainability concerns in literature education. Clark (2015, p. 197) suggestion for the future of ecocriticism entails overreading and extreme interpretation, using literary criticism to challenge the boundaries of thought and to counteract simplistic and unitary understandings of the world. The Anthropocene could be regarded as a condition that calls for defamiliarization (cf. Shklovsky 2017): what you perceive is actually likely something else, and though we may never know exactly what it is, you need to be aware of this fact. Climate change, Clark underlines following Timothy Morton (2013), is a hyperobject, defined as "entities whose physical and temporal scale and complexity overwhelm both traditional conceptions of what a thing is and what 'understanding' it could mean" (Clark 2015, p. 8). The question of what constitutes pro-environmental action in the Anthropocene, and thus what literature can do on this field, needs to take into account the challenge of perceiving and understanding ecology on a global scale. 
This analysis of the Anthropocene deals a further blow to the altruistic paradigm of ecocritical pedagogy. As Keen points out, even if empathy-induced altruism could be brought about by novels, it has liabilities, "such as harming the target of help, addressing some needs better than others, and inducing empathy-avoidance. Most seriously of all, empathy-induced altruism can lead to actions showing partiality rather than care for the common good and can result in injustice and immorality" (Keen 2010, p. 145). This is even more true in the Anthropocene, when it is far more difficult than we think to know which actions actually have the intended altruistic effects. In other words, it is not at all self-evident what perceiving oneself to be a part of nature and behaving accordingly would entail in practice (cf. Bergthaller 2010). Clark, however, is avowedly anti-fatalist: humans can use their intelligence to find solutions to the problem (Clark 2015, p. 11). This article thus constitutes an attempt to extrapolate some pedagogical implications of the Anthropocene as threshold concept.

To state the problem clearly, literary texts are too polysemic to provide clear guidelines on how to act; even if they could provide such guidelines, the way in which readers make sense of texts makes it impossible to govern exactly what guidelines they will acquire; even if we could find a way to make sure that readers did receive specific guidelines on sustainable behavior and acted accordingly, we would still have a tremendously complex task in figuring out what exactly constitutes sustainable behavior. And if we did find a way to do all this, we would still have to justify spending all that time and effort on making literature education do something that is so contrary to its nature, so to speak. Why should teachers of literature focus on inexpertly transmitting knowledge of ecological processes, rather than doing what they are actually experts in: teaching literature? In order to approach the question of what literature education can do, in the following section, I account for some basic assumptions concerning the literary reading process. These assumptions will in turn form the basis of the concept of sustainable literary competence.

\section{Literature as Ecology: From Suspicious Readings to Witty Suspicion}

Bergthaller's and Clark's criticism of ecocritical orthodoxy might usefully be considered in light of a more overarching recent tendency to reevaluate critical theory. Rita Felski argues that an unexamined cognitive maneuver in literary criticism is how "[w]e slide from close readings of works to causal claims about their social impact, as if these two activities were somehow synonymous" (Felski 2015, p. 171). In Felski's view, such claims are part and parcel of what she, following Paul Ricœur, terms "the hermeneutics of suspicion." She considers this the dominant mode of reading in post-poststructuralist literary studies, characterized by a "fault-finding mentality" aimed at improving the social world (ibid., p. 172). Felski's proposed alternative, "postcritique," has important roots in Eve K. Sedgwick's distinction between "paranoid" and "reparative" reading. While paranoia emphasizes "the efficacy of knowledge per se-knowledge in the form of exposure," "to a reparatively positioned reader, it can seem realistic and necessary to experience surprise" (Sedgwick 2003, pp. 138, 146). That is, where the paranoid reader seeks to anticipate what oppressive ideas might be found in the murky waters of the text, the reparative position is open to being both negatively and positively surprised. The reparative reading practice that Sedgwick calls for entails a willingness to risk being affected by a text in unpredictable ways.

Hence, Felski argues for the need to find ways of dealing with the power of literature to fascinate and trouble us. To revitalize literary studies, we need to take advantage of this power of fascination as a starting point for interpretation, instead of assuming that an immersive aesthetic experience is naïve and apolitical. Therefore, she calls for an affective hermeneutics, stating, "affective engagement is the very means by which literary works are able to reach, reorient, and even reconfigure their readers" (Felski 2015, p. 177). If the only approach to literary works is one of knowing, critical suspicion, and if we are never to let such works speak to our emotions, we lose the plethora of interpretative and affective engagement that arguably constitutes the value of imaginative literature.

Here, Felski finds support in a revival of hermeneutics in contemporary francophone theory. One important resource is Swiss theorist Yves Citton (2017) wide-ranging defense of the value of literary 
studies. In a Spinozist-Deleuzian fashion, Citton views literary texts as modal beings, i.e., phenomena that exist in an interplay with other phenomena (Citton 2017, p. 132). In this terminology, any reading of a text is virtual until a specific reader actualizes it; literary interpretation is therefore a relation between relations, an affection between affections, a codified structure of impressions (the text) encountering another structure of impressions (the reader). ${ }^{1}$ Hence, the experience of fiction "appears no longer as a flight away from the world (conceived as the only existing world, which it is only a matter of representing adequately), but as the moment of a constitutive process, participating actively in the transformation of the actual world of today into the actual world of tomorrow." ${ }^{2}$ Literary interpretation has world-making effects in that a singular interpretation of a text actualizes something that would otherwise remain virtual.

Furthermore, Citton (2017, p. 290) underlines how imaginative literature calls for a willing suspension of disbelief, but also a witty suspicion of all beliefs. I take this to mean not suspicion in the sense of suspicious or paranoid readings but, rather, suspicion as a term for how fiction makes us constantly question what we think, as it asks us to suspend our ideas of the world in an immersive experience (Citton 2017, p. 291). The power of a text to change the world is thus not a question of the reader arriving at a different conclusion about how the world works, but a question of how literature exhorts us to keep actualizing its virtuality, remaining in an ongoing process of questioning, wondering, and interpreting. This highlights an important aspect of the concept of polysemy outlined above: literary reading should be thought of as something that keeps thought in motion rather than providing the reader with final answers.

Where Citton mainly uses a vocabulary of affection, virtuality, and actualization, Felski presents an array of other concepts that help to describe the relations between texts and readers. Primarily, she draws on Bruno Latour's Actor-Network Theory (ANT), in which books can be described as "nonhuman actors" (Felski 2015, p. 164). However, she also calls attention to the idea of affordance (ibid.). This term was coined by psychologist James J. Gibson to describe how animals interact with the surfaces of their environments. A horizontal surface, for example, is "stand-on-able, permitting an upright posture for quadrupeds and bipeds. It is therefore walk-on-able and run-over-able. It is not sink-into-able like a surface of water or a swamp [ ... ]" (Gibson 2015, p. 119). Affordances could also be regarded as virtual, since, "for all we know, there may be many offerings of the environment that have not been taken advantage of [ ... ]" (ibid., p. 121), and relational because "affordance is neither subjective nor objective but arises out of the interaction between beings and things" (Felski 2015, p. 165). Without minimizing the differences between the various concepts and theoretical traditions which Felski refers to, I wish to underline how they all allow us to consider the relations between texts and readers as ecological. Here, it is useful to follow Morton's account of ecological thought as "the thinking of interconnectedness," "a practice and a process of becoming fully aware of how human beings are connected with other beings-animal, vegetable or mineral" (Morton 2010, p. 7). Just as Gibson develops the theory of affordances in a book titled The Ecological Approach to Visual Perception, ANT also rests on the idea that the non-human can be an actor by "[modifying] a state of affairs by making a difference" (Felski 2015, p. 163). From here, there is but a small leap to Citton's Spinozist ontology of literature as a modal being, capable of affecting and being affected.

Defining literature, and the text-reader encounter, as ecological is relevant to a sustainable literary competence, but not only because it is a neat metaphor. The idea of literature as ecology allows for a fuller description of what an Anthropocene reading practice can look like. For instance,

1 “Il ne s'agit pas ici d'esthétique au sens traditionnel d'une aisthesis faite d'affectionssensorielles [sic] directes, mais d'un jeu interne au code, d'un rapport de rapports, d'une affection entre affections : d'une structure codifiée d'impressions faisant face à une autre structure d'impressions" (Citton 2017, p. 201).

2 “L'expérience de la fiction n'y apparaît plus comme une fuite hors du monde (posé comme le seul monde existant, qu'il s'agirait uniquement de représenter adéquatement), mais comme le moment d'un processus constituant qui participe activement à la transformation du monde actuel d'aujourd'hui en monde actuel de demain" (Citton 2017, p. 268). 
Clark (2015, p. 63) underlines the way in which literary reading is marked by an anachrony paralleling the impossibility of a full overview of causes and effects created in the Anthropocene: " ... since writers will, necessarily, not be able much to predict the affect and the effects of reference that a text may produce in a future reader, it is always possible that new, unforeseen contexts will alter the text retrospectively ..." ". Defining literary reading as ecological thus also provides a helpful perspective on literary education. Indeed, theories of reading education have arguably stressed the unpredictable relation between text and reader more than disciplinary literary theory has. Notably, American scholar Louise Rosenblatt (1994) transactional theory of the literary work is a staple in literature education. But where "transaction" implies a controlled exchange of data from one pole to the other, the term "ecology" in my opinion better captures the polysemy and unpredictability described above. ${ }^{3}$ Literary reading is not a two-way event but depends on a larger context with multiple actors, or, in Citton's vocabulary, other structures of impression. Literature education takes place in a complex ecology of both sociocultural and physical factors, of texts, readers, teachers, educational policy documents, and classrooms-to name just a few.

If we move away from the hermeneutics of suspicion informing the altruistic paradigm, and instead think of literature as ecology, we will have a better chance at coming to terms with how literary texts playfully suspend our beliefs and thus actualize virtual worlds in unpredictable ways. However, integrating sustainability into literature education is also a question of ethics, since it takes a consequentialist ethics as a fundamental premise. Therefore, the following section aims to outline how literary reading can be understood as ethical.

\section{A Dark Literary Ethics}

As mentioned, an important point in Felski's vision of postcritical reading is to reject any accusations that the act of being fascinated or pleasantly or uncomfortably surprised by a text is simply a form of naiveté to be overcome by critical training. Where the suspicious reader believes that she is somehow placed outside of the text as an unaffected judge, postcritique draws attention to the fact that, as readers, we produce the readings which we assess. Thus, we analyze "ourselves" as much as the text "itself"; indeed, through an ecological lens, one might question the very assumption of the readerly self as distinguished from a unitary text. Zambian-American scholar C. Namwali Serpell, whom Felski cites as one of her inspirations for a postcritical reading practice, puts this succinctly by stating "any interpretation of American Psycho is [ ... ] an interpretation of the reader" (Serpell 2014, p. 216). This underlines the ethical aspects of literary reading and expresses a more complex view of literary ethics than the altruistic paradigm. Reader responses are highly individual, and one reader's distaste for a perceived morally repulsive character does not preclude the possibility that other readers may construe the same character as a role model. Different readers embody different structures of impression and generate readings that reveal much about what those structures are and can be.

In developing a thorough critique of contemporary thinking on literary ethics, Serpell (2014, p. 72) offers an alternative view of ethics as a process: reading is characterized by a swing back and forth between myself as reader and the textual other in a process of continuous identification and disidentification. This points to the complexity of the reading experience and leads Serpell to call for "infusing [ethics] with time, contradiction, disturbance, darkness," thus arguing for the value of uncertainty (Serpell 2014, p. 39). This view of ethics does have parallels in ecocritical pedagogy-for example in Garrard's description of how close reading of a poem can be experienced as at once intimate and strange, embodied and abstract (Garrard 2010, p. 242). However, such an ambivalence is most fully developed by Morton $(2007,2010)$ in his account of dark ecology and the ecological thought. Like Serpell, Morton draws attention to two important points: first, the unrest or uncertainty

3 While Rosenblatt uses the metaphor of ecology to describe reading, too, she does this only in passing, sticking to "transaction" as it is understood in Dewyan pedagogy. 
that literary texts are able to create in a reader and, second, the possibility of the reader to remain in this unrest, going back and forth between different viewpoints, possible interpretations, or points of indeterminacy.

Morton proposes to regard the ecological as a site of uncanny darkness, melancholy, and uncertainty. In his view, the romantic image of Nature as an "Other," distinct from the "human," hampers us from realizing the complex and disturbing interconnectedness which he calls "the mesh." Instead of viewing this conception of Nature as the goal of ecological thinking, Morton (2010, p. 54) argues that environmentalism needs to acknowledge the uncanny. He thus exhorts students of literature to reach the uncomfortable realization that all beings, including humans, are part of the same world of dependency. Coming to terms with this dependency, however, is disturbing; the mesh confronts us with everything that we do not know or understand, and everything in nature that is not aesthetically pleasing. Combining Serpell's account of the ethics of the reading process and Morton's ecological thought, one might claim that the ethical effect of reading literature is not one of positive identification with Nature as Other, but might as well be one of ambivalence, melancholy, or despair. These are negative affects that, following Felski, may nevertheless offer rich hermeneutic potential. At the same time, Morton provides an interesting nuance to Citton's praise of literary wit, as he instead pleads for the importance of irony. Riffing in this context on Stanley Cavell's reading of "The Rime of the Ancient Mariner," Morton states:

[ ... ] the Mariner 'accepts his participation as a being living with whatever is alive.' The 'whatever' is crucial. Ecology without nature needs the openness of this whatever, probably pronounced with the distracted yet ironic casualness of a Californian high school student. Otherwise the ecological collective to come will be captured by the fantasies of nation building that have haunted the concept of nature. (Morton 2007, p. 158)

Morton's highlighting of irony addresses a possible paradox that remains unaddressed in Citton's rather disingenuous idea that studying literature can save the world (cf. e.g., Citton 2017, p. 43). Because if we need to wittily suspect all beliefs, then that belief, too, needs to be suspected. Irony, in Morton's account, as I understand it, would be an attitude that says "I might mean what I say, but I also might not-whatever." This constant willingness to suspend one's judgment is indeed a form of wit, but a wit that needs to be couched in irony.

Importantly, however, this irony must be distinguished from cynicism. Morton (2012, p. 160) is wary of the smug knowingness characterizing, e.g., Marxist (suspicious) critiques of sustainable development and green consumption. Instead, he encourages the development of an irony "full of slightly sad, ambiguous tenderness". This is brought about by the practice of deconstruction, which to Morton "means realising, not that reality is colonised by text, but that there are weird pieces of physicality within texts, stuck in them like fossils in rock, and that if we examine them, we realise that there is no 'away'” (ibid., p. 159). Indeed, I understand Morton's description of deconstruction as a way of coming to terms with the existence of hyperobjects. It constitutes a reading practice that draws attention to the nonlocality of literary texts:

[ ... ] there is no such thing, at a deep level, as the local. Locality is an abstraction. Metaphorically this applies to hyper-objects. The wet stuff falling on my head in Northern California in early 2011 could have been an effect of the tsunami churning up La Niña in the Pacific and dumping it on the land, La Niña being a manifestation of global warming in any case. (Morton 2013, p. 47)

In a sense, this is another way of accounting for a ubiquitous term in contemporary literary studies, i.e., context. But again, the ecological metaphor-based on a view of the literary text as polysemic and affective-makes it clear how literary reading can be described as something other than transferring a predefined set of values. Textual work can help us to realize that there is no outside, no "hors-texte," but that a text always carries "evidence of garbage, dolphins, plutonium and styrofoam, quite literally" 
(Morton 2012, p. 159). Thus, a foundation is prepared for an ecological ethics: "Life is non-identical to itself. Ecology is the encounter with this non-identity, and ecological ethics is at the very least allowing the non-identical to exist" (ibid., p. 162). Textual work can allow the non-identical to exist. The matchbox can be a bat.

This ethical work entails a risk. To Serpell, literary texts fundamentally bring about a dynamic interplay between an I and a Thou. Following the terminology of Martin Buber, she underlines how ethics needs to encompass any ontological category-animate and inanimate non-human phenomena as well as humans. This relational ethics calls upon us to live in constant awareness of the dynamisms and conflicts in the I-Thou relation (Serpell 2014, p. 74). Like human encounters with human and non-human others, reading is risky in that we never know what it will bring about or how it may affect our "structure of impressions." The hermeneutics of suspicion, or paranoid reading, aims to avoid this risk. The empathy-altruism hypothesis, on the other hand, constitutes an attempt to harness the risk by pulling an authorized reading through the minds of students in the hope that some environmental awareness sticks. But what if we instead saw the risk, the openness to nonidentity, and the potential positive and negative affects as a possibility for ecological engagement with ethical effects? What could a literary ethics focused not on content but on literary form, as a starting point for a dive into the uncanniness of the mesh, look like?

At this point, educational scholar Alice Lesnick's ethnographic study of ethical engagement in literature education can be inspiring. Lesnick asserts that "the complicated potential of literary texts themselves as well as students' identities and ideas are under-utilized in classrooms as resource for experience, reflection and critical discussion," because the dominant views of literature as a source of role models or moral precepts "fail to take advantage of the complexity of students' experiences, belief systems and sense of responsibility as human beings as they intersect with those represented in literary texts" (Lesnick 2006, p. 30). This depiction of the text-reader encounter is fundamentally hermeneutic. It echoes Citton's account of the confrontation between structures of impression and highlights how the unpredictable polysemy of a text can be a resource in ethical engagement. Defining ethics as "a domain in which people share in and make sense of experience not only to resolve particular problems but also to learn and grow as caring and responsible individuals in essential relationship to others" (ibid., p. 29), Lesnick argues that "ethically meaningful interactions occur as part of the ongoing work of reading, writing, and conversing in school" because "literary study [ ... ] brings experiences of language, culture, identity, imagery, metaphor, narrative, beauty mystery and history into focus and into play as people create relationships with one another through and with texts" (ibid., p. 43). Here, one could note the proto-postcritical prioritizing of affect as foundation for interpretative work. Lesnick describes the power of literature to touch and unsettle, focus, and disturb the reader-and the metaphor of bringing different experiences into play also speaks to the witty, experimental, and, one might say, juvenile (in a valuable sense) nature of literary engagement.

Granted, Lesnick's approach could be criticized for being teleological and oriented towards a Nussbaumian conception of compassion as a result of literary reading. However, one might equally well read her study as describing reading as a process of continuous reflection rather than as goal-oriented. The objective is to capture and make use of what actually happens in reader-text encounters rather than bending literary texts into serving a specific "knowledge deficit" project. Furthermore, the pedagogical practices which Lesnick describes are fundamentally dialogic in nature: students are engaged in written and oral dialogue with their teachers and other students concerning their responses to texts. Hence, Lesnick (2006, p. 40) observes a complex intertextuality with ethical implications: "part of what people do in the ethical domain is to import assumptions, beliefs, vocabularies and stories from other sources and use them in constructing responses to present phenomena". In this way, her account of the ethics of literature education is based on dialogic and sociocultural theories of learning. Such theories assume that knowledge is developed socially and regard the classroom as a space for open inquiry to foster subject-specific competence (Wertsch 1991; Langer 2011). This forms a key linking point between 
the ecological theory of literary reading developed above and its classroom application in developing a sustainable literary competence.

To Morton, a fundamental barrier to ecological thinking is the idea that there is such a thing as Nature that can be clearly objectified, much like patriarchy objectifies Woman (Morton 2010, p. 5), and that appears only in certain texts, not in others. "In a world properly attuned to the environment," he states, "we would read poems with an eye to ecology, no matter what their content" (Morton 2007, p. 79). As a slogan for ecological thinking, this is great, but what can it entail for ES? How can the "we" of the classroom read with an eye to ecology? What ES competences can literary education be expected to foster, and how? To venture an answer, the following two sections parse out what sustainability competence is expected to entail and discuss how the description of literature, ecology, and ethics can be helpful in operationalizing this in literary education.

\section{The Overlaps between Literary Competence and Sustainability Competence}

A helpful and much-used definition of ES stems from a synthesis by sustainability researchers Wiek et al. (2011). Comparing natural science findings, policy documents, and curricula, these authors identify five key competences in sustainability: systems-thinking, anticipatory, normative, strategic, and interpersonal. Figure 1 illustrates these competences and their role in the framework of sustainability research and problem-solving. The model of Wiek et al. is one of the bases also for UNESCO's most recent guide of learning objectives for sustainability (UNESCO 2017). The UNESCO definition is somewhat more fine-grained, as it highlights collaboration, critical thinking, and self-awareness as separate competences. However, the strength of Wiek et al.'s model is its inclusion of epistemological pluralism and critical evaluation of different viewpoints in the overarching concept of interpersonal competence. This entails the recognition that critical thinking is a social act, as it involves evaluating and reflecting upon the ideas of someone else, and since taking a stand-interpretative and/or political-is also a way of performing an identity and participating in a social group.

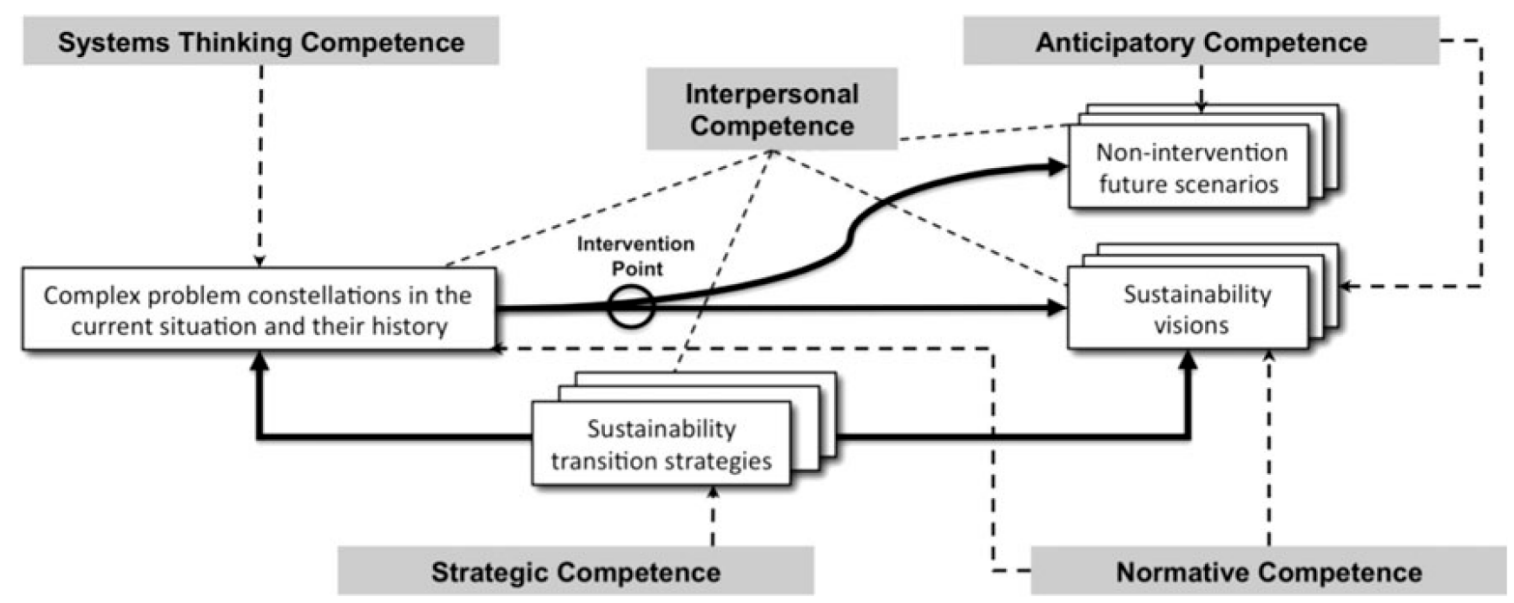

Figure 1. "The five key competencies in sustainability (shaded in grey) as they are linked to a sustainability research and problem-solving framework [ ... ]. The dashed arrows indicate the relevance of individual competencies for one or more components of the research and problem-solving framework [ ... ]" (Wiek et al. 2011, p. 206).

The altruistic paradigm and information deficit models arguably address the development of normative competence, i.e., "the ability to collectively map, specify, apply, reconcile, and negotiate sustainability values, principles, goals, and targets" (Wiek et al. 2011, p. 209). However, I would argue that systems-thinking and interpersonal competence stand out as more relevant competences for literature education. While the former denotes "the ability to collectively analyze complex systems across different domains [... ] and across different scales," the latter is crucial for acknowledging and evaluating epistemological pluralism (Wiek et al. 2011, pp. 207, 211). 
What then, are the affordances, in ecological terms, of literary education for the various sustainability competences? One might answer this by turning to a much cited roadmap for what literary competence entails. Based on classroom experience and both pedagogical and literary theory, American high school and college educator Sheridan Blau presents literary competence as consisting of three domains of knowledge: (1) textual literacy, or procedural knowledge, encompassing critical thinking, knowing how to go about a literary analysis, and the ability to "read the world"; (2) intertextual literacy or informational knowledge, including cultural literacy and the ability to perceive connections between different texts and cultural domains; (3) performative literacy or enabling knowledge, consisting of seven dimensions (Blau 2003, pp. 203-11). The first knowledge domain involves the ability to decode and interpret a text-the know-how aspect of literary competence. Always attentive to the implications of literary competence for other, more general skills, Blau suggests that textual literacy is identical to critical thinking in general, and that learning how to interpret literary texts equals learning how to read all texts, and thus the social world as such (Blau 2003, p. 205). While this is indeed a bold claim, it illustrates how literary competence is transferable and how it can form part of systems-thinking as well as interpersonal competence.

The second knowledge domain involves the cultural knowledge necessary for making sense of a text. Following Julia Kristeva (1969) conception of intertextuality as fundamental to textual meaning, Blau highlights the importance of being acquainted with certain references to arrive at a particular interpretation. It is useful, however, to acknowledge that even teachers, as expert readers, often depend upon accidental bits and pieces of intertextual knowledge to make sense of canonical texts. Hence, to Blau, it is important that teachers "do not exaggerate for themselves or for their students their own virtuosity as interpreters of texts and, by comparison, the insufficiency of student readers" (Blau 2003, p. 207). This point is pedagogically useful as it democratizes participation in the literary classroom. However, one might take an even more radical approach, as does Citton, in arguing for the productive tension between texts and readers. Citton claims that lacking the references of the majority culture may be an advantage if the aim is to encounter the text as openly as possible (Citton 2017, p. 236). For example, if Hamlet is the text to be discussed, a native speaker of English will likely be influenced by a host of prior conceptions (and misconceptions and prejudice) on Shakespeare, which a student from a different culture probably does not share. The latter student, however, will have other references, stories, and cultural norms that may be helpful in producing readings which the teacher-or, indeed, the author-would never think of. While Blau's notion of intertextual literacy thus comes close to E.D. Hirsch (1987) idea of "cultural literacy" as a question of possessing the "right" references, one might follow Citton in claiming that it is indeed impossible to know a priori what cultural references-what sort of intertextual literacy-will contribute to interesting and creative interpretations. This, then, illustrates the potential of literature education to use cultural diversity as a resource for democratic and intercultural training. It could therefore be regarded as supporting interpersonal literacy, of which "[ $\mathrm{t}$ ] he capacity to understand, embrace, and facilitate diversity across cultures, social groups, communities, and individuals" is a key component (Wiek et al. 2011, p. 211). If literary education forces readers to be confronted with the understandings of other readers, one has a basis for discussing the following questions: why do you hold this interpretation? To what extent are other interpretations possible? How can this text be non-identical to itself? Developing intertextual literacy is thus also a question of becoming aware of one's cultural and intellectual baggage and how it influences one's understanding of texts and the world.

Blau's third knowledge domain stands in contrast to what he terms pseudoliteracy, which is an educational practice that he laments as far too common:

the kind of literacy that students acquire when they depend on authoritative sources for their readings of difficult texts or when they have been convinced by their instructional experience not that they are capable of making sense of texts that at first seem unintelligible, but that any encounter they have with such a text is evidence that they are insufficient readers $[\ldots]$. (Blau 2003, p. 210) 
Hence, Blau distinguishes seven dimensions of performative literacy: a capacity for sustained, focused attention; a willingness to suspend closure; a willingness to take risks; a tolerance for failure; a tolerance for ambiguity, paradox, and uncertainty; intellectual generosity and fallibilism; and metacognitive awareness (ibid., p. 211). Ideally, then, a competent reader is able to approach literary texts knowing that she may not understand everything, but that the confusion which a text generates is a valuable starting point for developing understanding. Moreover, a competent reader is metacognitively aware of the strategies she uses to develop understanding. She is willing to suggest interpretations and verbalize her nascent understanding to others, accepting the risk of making mistakes and suffering respectful counterarguments. And she works patiently with the text, accepting that, in the end, she may not arrive at a full understanding. In short, a competent reader is able to value the explorative process and the many (ethical, linguistic, aesthetic) questions that may surface, rather than working to attain a final, complete understanding.

Such a reader, if she could transfer this "genuine" literacy to other areas, would arguably possess much of what Wiek et al. describe as interpersonal, systems-thinking, and anticipatory competences. Intellectual generosity and fallibilism are obviously important in interpersonal and intercultural communication. As mentioned, systems-thinking is the ability to "analyze complex systems across different domains [ ... ] and different scales" (Wiek et al. 2011, p. 207). It entails "an intimate understanding of the inner fabric and dynamics of complex social-ecological systems" and could also be termed "holistic thinking" (ibid.). Thus, it demands many of the same skills as does Blau's definition of performative literacy. This could also be linked more specifically to Clark's description of an Anthropocene reading practice, which is based on overreadings that entail their own intellectual risk: "Environmental criticism now finds itself having to break down intellectual barriers that in the past gave its own procedures and objects relative separateness and coherence" (Clark 2015, p. 197). In other words, we cannot produce literary readings by making tacit assumptions about what contextual elements are important anymore, nor can we anchor a text firmly in a perceived "original" context. Even a poem can make us aware of the existence of hyperobjects; it is "caught between worlds, in an interstitial place that makes worlds as such seem flimsy and constructed-which, of course, they are" (Morton 2013, p. 53). While this might be a challenge to teachers of literature, it could also be liberating in that it allows for the kind of actualizing, democratic readings that Citton envisions. The role of ecocritical theory here could thus be that of underlining how the Anthropocene forces us to adopt a literary reading practice that fosters the epistemological humility and constant intellectual work required in sustainable citizens.

Prepared to take risks, tolerate failure, and accept her own fallibilism, the competent reader also has a foundation for anticipatory competence, defined as the ability to produce "pictures of the future" (Wiek et al. 2011, p. 209). Indeed, a key component of literary reading is being able to produce images from the structures of the text by filling in its "gaps" (Iser 1984), and especially narrative fiction exhorts the reader to anticipate what will happen. But a pseudo-literate reader will be blocked from producing independent, creative, and intellectually robust anticipations and instead reproduce socially accepted interpretations-at best. If ES is to be integrated into literature education, it therefore needs to develop the performative literary competence that Blau describes. Table 1 summarizes the correspondences between literary competence and sustainability.

One final point that merits particular attention is the close connection between sustainability competences and democratic skills. Indeed, as argued above, the perhaps most distinguishing feature of literary competence in relation to ES is the potential of literature for cultivating a reader's tolerance for epistemological pluralism and uncertainty, as well as a readiness to accept that all knowledge is preliminary. The Anthropocene makes us even more aware of the fact that there is no easily identified, unitary context that gives us the keys to understanding a text fully. Therefore, Clark argues that rather than attempting to unify the disparate elements of a complex literary text, "a reader might stay with this disjunctiveness" (Clark 2015, pp. 64-5). Morton, too, underlines the importance of constantly questioning reified notions, such as "Nature," because they stop the process of thinking: "Thinking, 
when it becomes ideological, tends to fixate on concepts rather than doing what is 'natural' to thought, namely, dissolving whatever has taken form" (Morton 2007, p. 24). As noted above, such a notion is hardly unique to ecocritical or ecological theory but could be considered fundamental to many theories of literature as art form and literary reading as practice. For example, Paul Armstrong argues for a reading practice guided by the norm of "nonconsensual reciprocity," which assumes "parity between the worlds of text and reader", implying that "the authority of the conventions governing both are at play and at risk" (Armstrong 2005, p. 8). Similar arguments are at play in Blau's notion of literary competence, which is fundamentally egalitarian in that it assumes equality between teacher and student in textual interpretation.

Table 1. The relation between types of sustainability competence and factors of literary competence.

\begin{tabular}{cl}
\hline $\begin{array}{c}\text { Sustainability Competence } \\
\text { (Wiek et al. 2011) }\end{array}$ & \multicolumn{1}{c}{ Corresponding Factors of Literary Competence (Blau 2003) } \\
\hline Systems-thinking & $\begin{array}{l}\text { Textual literacy, i.e., critical thinking. } \\
\text { Performative literacy, especially capacity for sustained, focused } \\
\text { attention, willingness to suspend closure, tolerance for ambiguity, } \\
\text { paradox, and uncertainty and metacognitive awareness. }\end{array}$ \\
\hline Anticipatory & $\begin{array}{l}\text { Performative literacy, especially willingness to take risks, tolerance for } \\
\text { failure and intellectual generosity and fallibilism. }\end{array}$ \\
\hline Normative & $?$ \\
\hline Strategic & $?$ \\
\hline Interpersonal & Textual literacy, i.e., reading the world and critical thinking. \\
& $\begin{array}{l}\text { Intertextual/cultural literacy. } \\
\text { Performative literacy, especially willingness to take risks and intellectual } \\
\text { generosity and fallibilism. }\end{array}$ \\
\hline
\end{tabular}

Therefore, one could argue that the interpersonal and systems-thinking competences to which the literary classroom can contribute form a point of connection with political theorist Derek R. Bell's idea of liberal environmental citizenship. Bell suggests grounding this in a conception of citizens as "citizens of an environment." Here, "environment" is in turn conceived as a provider of basic needs and "'a subject about which there is reasonable disagreement"' (Bell 2005, p. 185). Such a conception of environmental citizenship overlaps with what Owens identifies as a consensus that "environmental values are not necessarily preformed or fixed, waiting to be revealed or articulated, but 'emerge out of debate, discussion and challenge, as [people] encounter new facts, insights and judgements contributed by others'" (Owens 2000, p. 1145). As mentioned, the fact that the term "sustainability" lacks precision may prove useful to integrate ES in literature education — not because it allows us to create a radically new definition to fit the needs of literary studies, but because ES has to be a type of education enabling people to cope with reasonable disagreement. Here, literature plays a part in stimulating (uncynical) irony and witty suspicion. If sustainability is dependent on the critical, democratic skills of the public, we need to embrace the dark, ironic, and uncertain ethical discussions that literary works generate in order to cope with the Anthropocene. This would constitute a sustainable literary competence.

\section{The Playful Risk of the Literary-Ecological Classroom}

What is needed in literary reading —and, indeed, in a sustainable citizen—is the ability to take intellectual risks, be surprised by what a text provides as structure of impressions, and patiently explore it. In fact, ES and ecocritical pedagogy have long promoted slow, stable thinking and discussion (Holt 2005; Morton 2012, p. 163). This is the basis for "sustained, focused attention" (Blau 2003, p. 211) and for cultivating a reading experience marked by ethically productive "time, contradiction, disturbance, darkness" (Serpell 2014, p. 39). What, more specifically, would a classroom stimulating these competences, the literary-ecological classroom, look like? 
The distinction developed above between the altruistic paradigm and sustainable literary competence could be mapped onto Rosenblatt's famous distinction between efferent and aesthetic reading. In efferent reading, the reader is focused on acquiring information that will be useful after the reading- "efferent" deriving from a Latin verb meaning "to carry away." In aesthetic reading, on the other hand, the reading process itself is the main point: "the reader's attention is centered directly on what he is living through during his relationship with that particular text" (Rosenblatt 1994, p. 25; emphasis in original). In other words, time is a crucial dividing line between efferent and aesthetic reading. Aesthetic appreciation is slow; it demands dwelling, slow thinking, and patience. Indeed, if we read to "carry away" something, we might read fast, as—using Rosenblatt's own example- the mother who studies the bottle of detergent for information of its contents, swallowed by her toddler. But reading a novel fast is tantamount to not reading it at all (Rosenblatt 1994, p. 24). It is important to note that these two stances are extremes on a continuum: a reader of a well-written informational text might well aesthetically appreciate the stylistic choices made by the author, while the reader of a poem might consider what the poem teaches her about existential questions while she is enjoying it as a work of art. Nevertheless, the helpful insight of Rosenblatt's work in this context is her insistence that approaches to readings are stances that have to be learned. Instead of thinking of ES in literary education as having to do with gleaning information from a text (efferent reading), we might perhaps more reasonably think of it as having to do with cultivating a particular stance towards the world, the texts we encounter, and the conversations we have about them.

Thus, the place of ES in literature education is not primarily a question of what we read, but about how we read. In much the same way as gender and queer theory and postcolonial studies have developed ways of producing counterintuitive readings of the canon, the Anthropocene reading practice that Clark calls for would encourage discussions of connections and connotations that are not readily identifiable - thus allowing pupils to become aware of hyperobjects. However, in contrast to a hermeneutics of suspicion, an Anthropocene reading would cultivate a "witty suspicion of all beliefs" (Citton 2017, p. 290), and irony. It would look more like seeing a bat where there is apparently only a matchbox than seeing anthropocentrism in a subtext. If this sounds like play more than solemn, methodical analysis, so much the better. Like Rosenblatt's idea of an aesthetic stance, witty suspicion and irony are also stances. They potentially form part of a reader's structure of impressions, allowing her to perceive elements that would otherwise go unnoticed. What luck that such stances overlap with the competences of sustainability!

As indicated above, a central point of connection between the aesthetic stance and sustainability competence is the idea of risk. One could argue that ecocriticism has traditionally been more intent on avoiding risk, as it is only one of many theoretical schools directed towards uncovering the ideologies of a text, from the assumption that such uncovering will change the minds of readers. But apart from the other problems described in Section 1, this faith in exposure also evades critical analysis of a more fundamental pedagogical assumption: How is a teacher to know whether the environmental attitudes "uncovered" in a text are not already known to students? Empirical ecocriticism exemplifies one of the potential problems with this. Schneider-Mayerson (2018, p. 479) notes that because readers of climate fiction are younger, more liberal, and more concerned about climate change than the average reader, "it seems unlikely that these works would function as Trojan horses for message smuggling". While he goes on to suggest that literature has the potential to nudge readers already concerned about climate change to take more direct action, this still begs the question discussed in Section 2 of whether this is the most useful way to think about literature education and sustainability. In assuming that ecocritical readings will make the young people who go on strike every Friday more aware of the importance of environmental action, the champions of the altruistic paradigm are more likely to miss the target than to bring about real change.

The reparative reader, then, shows literary competence in being a risk-taker. And there is no reason not to demand such risk-taking, exactly because it is couched in play. As Doris Sommer remarks: "[ ... ] the best training ground for judgment is the carefree area of aesthetics. The reason is simple: 
deciding if something is beautiful requires responding to an intense experience but obeying no established principles, and this decision is therefore free from prejudice" (Sommer 2014, p. 3). This, again, aligns with irony and wit. The aesthetic experience is world-changing because it changes the structures of impression of the reader, but it is ironic because it entails no fatal risk. And is such a controlled risk not what reading literature is all about? Are not the best literary texts those which challenge the boundaries of language, providing the reader with a mixed experience of aesthetic pleasure and discomfort?

Understood in this way, literature could be regarded as a training lab for affects. Citton offers the image of hacking to illustrate this:

The literary classroom would benefit from turning into a hacker's lab where everyone, rich on his or her own resources, helps the others cobble together interpretations, outgrowths, games, remediations, intermediations, and transmediations that help us live, imagine, and think together on our little piece of Earth about to overheat. ${ }^{4}$

While the remark on global warming seems almost like an afterthought, such exploratory work may actually form a fundamental part of sustainability competence.

The idea of the literary classroom as a hacker's lab corresponds to a larger tendency to employ a radical aesthetics in literature education. British scholar Isobel Armstrong in many ways anticipates Felski's critique of the hermeneutics of suspicion when she writes, " $[\ldots]$ the politics of the anti-aesthetic rely on deconstructive gestures of exposure that fail to address the democratic and radical potential of aesthetic discourse" (Armstrong 2000, p. 2). Far from politically naïve, aesthetic experience is in itself an experience of change and thus has transforming potential. This idea of radical aesthetics has become an important trend in Scandinavian L1 education (cf. Aulin-Gråhamn et al. 2004; Smidt 2018). For example, Swedish scholar Jan Thavenius ironizes over the Enlightenment orthodoxy in ways that echo the abovementioned critique of ecocritical orthodoxy:

As long as pupils are told about drugs, racism, and sexual harassment, they will become conscious and knowledgeable. [ ... ] Pupils surely have an intelligence they can develop. But they also have needs and dreams that run counter to reason. Their lips can provide the answer school expects, but at the same time they think and feel something quite different. Pedagogy faces something far more complex than Enlightenment. ${ }^{5}$

Hence, he argues that instead of considering aesthetics as an add-on in school and society, it should be viewed as a way of seeking discussion and confrontation. It means using the methods of art to create knowledge, "when pupils and teachers work openly and creatively with their own knowledges and those of others, those of science well as those of personal experience and art." ${ }^{6}$ Theories of radical aesthetics highlight the transformative potential of aesthetic experience as not only something a student is subject to; aesthetic experience is also about students creating something in the institutional context of the literary classroom. A radical aesthetics starts from the assumption that there are special aesthetic qualities in literary works of art but would take an ironic—in Morton's sense-attitude towards reading, interpreting, and discussing them.

This theoretical framework could justify the use of an array of different teaching methods, and while methodology is not the key issue of this article, one could briefly outline some possibilities.

4 'La salle de classe littéraire gagnerait à devenir un hackers' lab où chacun(e), riche de ses ressources propres, aide les autres à bricoler des interprétations, des excroissances, des jeux, des remédiations, des intermédiations et des transmédiations qui nous aident à vivre, à imaginer et à penser ensemble sur notre petit bout de Terre en train de surchauffer" (Citton 2017, p. 485).

5 "Bara eleverna får höra och läsa om droger, rasism och sexuella trakasserier, blir de medvetna och insiktsfulla. [ ... ] Eleverna har förvisso ett förnuft som de kan utveckla. Men de har också behov och drömmar som strider med förnuftet. Deras läppar kan ge det svar som skolan förventar sig, men samtidigt tänker och känner de något helt annat. Pedagogiken står inför något mycket mer komplext än ren upplysning" (Thavenius 2004, p. 111).

6 “... När elever och lärare arbetar öppet och skapande med egna och andras kunskaper, vetenskapens likaväl som erfarenhetens och konstens" (Thavenius 2004, p. 121). 
Blau (2003) primary approach is what he calls a literature workshop where a crucial factor is the teacher's ability to help students to become metacognitively aware of what happens in their encounters with texts. This method is heavily reliant on reading and re-reading, suggesting that close reading, interspersed with organized discussion, is another promising approach. Here, one could look to Matt Copeland (2005) method of Socratic circles, as well as scholarship on what types of questions foster open, engaged discussion (cf. Wei et al. 2018). Apart from discussion, however, one might well explore an array of other methods suited to students of different age groups and different backgrounds. Aesthetic response in the form of drama or graphic art also constitute ways of responding to texts, and as adaptations, such responses arguably separate form from content, allowing a teacher to draw attention to the effects of either or both (cf. Hutcheon and O'Flynn 2013, pp. 9-10). Of course, such "adaptational" response can also come about in a simple writing assignment. Toril Moi tells the fascinating story of how Søren Kierkegaard attempted to clarify for himself the meaning of the story of Abraham and Isaac. Kierkegaard rewrote the tale four times, from the perspective of the different protagonists. Moi (2017, p. 189) parenthetically asks: "(Why don't we ask our students to do this sort of thing more frequently?)".

Like Lesnick's description of ethics in literature education, all of the methods suggested here rest on a sociocultural view of knowledge. The idea is to construct a literary-ecological classroom where readers and texts, as different structures of impression, are able to affect each other. Classroom practice should focus on the interpretive process, and the disjunctions and ambiguities produced in it. And "classroom" here of course refers to any institutionalized context of learning, not only a physical room. Digital media, for instance, allow for exploratory talk to take place in a variety of formats.

In the context of literary pedagogy, however, the question of which texts to select might be even more salient than how to teach. This is even more true as a design of teaching methods more usefully starts from teaching objectives and the texts selected to support specific outcomes. Here, one could draw inspiration from another ongoing trend in Scandinavian L1 research: an interest in exploring the effects of challenging texts. For instance, Margrethe Sønneland has shown how lower secondary pupils respond to short stories by Franz Kafka, Roy Jacobsen, and Raymond Carver. Her findings support the idea of presenting even pupils at lower levels with texts that give them real, domain-specific problems to discuss. According to Sønneland (2019, p. 25), the literary texts which we use should offer "cases of disturbance". It does make sense from a literary competence point of view as well as from a sustainability competence point of view to offer pupils and students texts where a clear interpretation is not readily available. Again, one could think of Morton (2012, p. 165) account of deconstruction: "The essence of deconstruction is realising you don't have to believe everything you think. At the same time you realise that you are stuck in your reality. There is some kind of ironic gap between the openness and the stuckness". Becoming aware of this ironic gap is something that literature education can facilitate. That would entail an Anthropocene reading practice and contribute to some, but not all, of the specific sustainability competences that we currently consider as decisive.

\section{Concluding Remarks}

The main tenet of this article is that, as educators, we cannot harness literary texts to serve the function of providing students and pupils with the right knowledge, values, and moral attitudes. While critical readings and discussions of concepts such as nature, the non-human, and sustainability in literary texts are doubtlessly useful, this is likely not the most relevant approach to integrating ES in literature education. In this sense, the preceding discussion has been an attempt to overturn the usual question of ecocritical pedagogy: not "what can literature do for ES?" but "what can ES do for literary education?" Hence, the preceding discussion constitutes an attempt to produce a theoretical framework for a sustainable literary competence. The objective of this concept is to draw attention to how issues in ES can serve as a tool to justify particular theories and methodological approaches in the teaching of literature. Hence, ES should not be regarded as a distracting add-on in the literary classroom, but as usefully integral to literature education in the Anthropocene. The notion of 
sustainable literary competence is couched in a definition of literature and literary reading as ecological phenomena. Furthermore, such a conception of literature has consequences for how we might best describe literary ethics. Following postcritical theory and Morton's idea of ecology, literary ethics is conceived as a question of process and of developing an ability to cope with ambiguity and uncertainty. Hence, the notions of witty suspicion of all beliefs, irony, and risk stand out as relevant categories to describe the attitudes of a sustainably competent reader of literature. These notions also overlap with a dialogic understanding of the literary competence relevant to language arts subjects across school types and age levels. By pinpointing the connections between literary competence and sustainability competences, one can identify further reasons to prioritize an exploratory, dialogue-based approach to literature education.

As Kollmuss \& Ageyman note, "the question of what shapes pro-environmental behavior is such a complex one that it cannot be visualized in one single framework or diagram" (Kollmuss and Agyeman 2002, p. 248). Sustainability competence needs to be conceived as composite, complex, and open to constant change as our knowledge of ecological changes and the effects of human actions are constantly revised. Literature can help us to handle such complexity, not because it provides us with models for pro-environmental behavior, but because learning to read literature competently entails learning to critically evaluate and re-evaluate opinions, postponing conclusions, and acknowledging that several diverging viewpoints can be reasonable at the same time. We need to spend time probing into, discussing, and failing to understand complex texts. This is not a panacea against environmental disaster, but it does amount to one brick in the edifice of sustainability, and probably the one that literature has the best chance of contributing to.

Because of the complexity of the issue, I have refrained from going into detail on texts or methods to use in developing sustainable literary competence. Hopefully, this concept can function as a possible category for reflecting upon the choice of texts, particularly for educators seeking alternative approaches to integrating ES in the classroom.

Granted, envisioning a privileged place for literary education in the often overcrowded L1 subjects of western schools, or in the marginalized Humanities departments of western universities, might seem idealist. But because literature education has the potential to foster ways of thinking that overlap with much-coveted sustainability competences, one might hope that ES could be a way of indicating the value of literature and literary studies. And perhaps a more clearly and modestly defined approach to literature and ES might be a more efficient way of defending literature than the more wide-ranging and less specific claims of ecocritical orthodoxy? In the context of the Anthropocene, we might well leave it to the natural sciences to attempt to find and communicate the right answers to the many problems brought about by environmental degradation, and turn to literature to get used to surprises, ambivalent ethical engagement, and intellectual fallibilism.

Funding: This research received no external funding.

Conflicts of Interest: The author declares no conflict of interest.

\section{References}

Armstrong, Isobel. 2000. The Radical Aesthetic. Oxford: Blackwell Publishers.

Armstrong, Paul B. 2005. Play and the Politics of Reading: The Social Uses of Modernist Form. Ithaca: Cornell University Press.

Aulin-Gråhamn, Lena, Magnus Persson, and Jan Thavenius. 2004. Skolan och den radikala estetiken. Lund: Studentlitteratur. Barthes, Roland. 1970. S/Z. Paris: Seuil.

Bell, Derek R. 2005. Liberal Environmental Citizenship. Environmental Politics 14: 179-94. [CrossRef]

Bergthaller, Hannes. 2010. Housebreaking the Human Animal: Humanism and the Problem of Sustainability in Margaret Atwood's Oryx and Crake and The Year of the Flood. English Studies 91: 728-43. [CrossRef]

Blau, Sheridan. 2003. The Literature Workshop. Teaching Texts and Their Readers. Portsmouth: Heinemann. 
Burgess, Jacquie, Carolyn M. Harrison, and Petra Filius. 1998. "Environmental Communication and the Cultural Politics of Environmental Citizenship". Environment and Planning A 30: 1445-60. [CrossRef]

Citton, Yves. 2017. Lire, Interpréter, Actualiser. Pourquoi Les études LittéRaires? Paris: Éditions Amsterdam.

Clark, Timothy. 2015. Ecocriticism on the Edge: The Anthropocene as a Threshold Concept. London: Bloomsbury Academic. Copeland, Matt. 2005. Socratic Circles: Fostering Critical and Creative Thinking in Middle and High School. Portland: Stenhouse Publishers.

Felski, Rita. 2008. Uses of Literature. Oxford: Blackwell.

Felski, Rita. 2015. The Limits of Critique. Chicago and London: University of Chicago Press.

Garrard, Greg. 2007. Ecocriticism and Education for Sustainability. Pedagogy 7: 359-83. [CrossRef]

Garrard, Greg. 2010. Problems and Prospects in Ecocritical Pedagogy. Environmental Education Research 16: $233-45$. [CrossRef]

Gibson, James J. 2015. The Ecological Approach to Visual Perception. New York: Psychology Press. First published in 1979.

Goldin, Ian, and Mike Mariathasan. 2014. The Butterfly Defect: How Globalization Creates Systemic Risks, and What to Do about It. Princeton: Princeton University Press.

Hale, Dorothy. 2007. Fiction as Restriction: Self-Binding in New Ethical Theories of the Novel. Narrative 15: 187-206. [CrossRef]

Hirsch, Eric D. 1987. Cultural Literacy: What Every American Needs to Know. Boston: Houghton Mifflin.

Holt, Maurice. 2005. The Slow School: An Idea Whose Time Has Come? In Ecological Literacy: Educating Our Children for a Sustainable World. Edited by Michel K. Stone and Zenobia Barlow. San Francisco: Sierra Club Books, pp. 56-63.

Hutcheon, Linda, and Siobhan O'Flynn. 2013. A Theory of Adaptation, 2nd ed. London and New York: Routledge. Iser, Wolfgang. 1984. Der Akt des Lesens. Theorie ästhetischer Wirkung. München: Wilhelm Fink.

Keen, Suzanne. 2010. Empathy and the Novel. New York: Oxford University Press.

Kollmuss, Anja, and Julian Agyeman. 2002. Mind the Gap: Why Do People Act environmentally and What Are the Barriers to Pro-environmental Behavior? Environmental Education Research 8: 239-60. [CrossRef]

Kristeva, Julia. 1969. Sēmēiotikē: Recherches Pour Une Sémanalyse. Paris: Seuil.

Langer, Judith A. 2011. Envisioning Knowledge: Building Literacy in the Academic Disciplines. New York and London: Teachers College Press.

Lesnick, Alice. 2006. Forms of Engagement: The Ethical Significance of Literacy Teaching. Ethics and Education 1: 29-45. [CrossRef]

Massey, Geraldine, and Clare Bradford. 2011. Children as Ecocitizens: Ecocriticism and Environmental Texts. In Contemporary Children's Literature and Film: Engaging with Theory. Edited by Kerry Mallan and Clare Bradford. London: Palgrave Macmillan, pp. 109-26.

McKeown, Rosalyn, and Charles Hopkins. 2003. EE $\neq$ ESD: Defusing the worry. Environmental Education Research 9: 117-28. [CrossRef]

Mercer, Neil. 2000. Words and Minds: How We Use Language to Think Together. London: Routledge.

Moi, Toril. 2017. Revolution of the Ordinary: Literary Studies after Wittgenstein, Austin, and Cavell. Chicago: The University of Chicago Press.

Morton, Timothy. 2007. Ecology without Nature. Rethinking Environmental Aesthetics. Cambridge and London: Harvard University Press.

Morton, Timothy. 2010. The Ecological Thought. Cambridge and London: Harvard University Press.

Morton, Timothy. 2012. Practicing Deconstruction in the Age of Ecological Emergency. In Teaching Ecocriticism and Green Cultural Studies. Edited by Greg Garrard. Basingstoke: Palgrave Macmillan, pp. 156-66.

Morton, Timothy. 2013. Hyperobjects: Philosophy and Ecology after the End of the World. Minneapolis: University of Minnesota Press, vol. 27.

Nussbaum, Martha C. 1997. Cultivating Humanity: A Classical Defense of Reform in Liberal Education. Cambridge/London: Harvard University Press.

Owens, Susan. 2000. 'Engaging the Public': Information and Deliberation in Environmental Policy. Environment and Planning A 32: 1141-48. [CrossRef]

Owens, Susan. 2003. Is There a Meaningful Definition of Sustainability? Plant Genetic Resources 1: 5-9. [CrossRef]

Report of the World Commision on Environment and Development: Our Common Future. 1987. Available online: https://sustainabledevelopment.un.org/content/documents/5987our-common-future.pdf (accessed on 1 December 2020). 
Rosenblatt, Louise. 1994. The Reader, the Text, the Poem: The Transactional Theory of the Literary Work. Carbondale: Southern Illinois University Press.

Sartre, Jean-Paul. 1988. "What Is Literature?" and Other Essays. Translated by Bernard Frechtman, Jeffrey Mehlman, and John MacCombie. Cambridge: Harvard University Press.

Schneider-Mayerson, Matthew. 2018. The Influence of Climate Fiction: An Empirical Survey of Readers. Environmental Humanities 10: 473-500. [CrossRef]

Schneider-Mayerson, Matthew, Alexa Weik von Mossner, and W. P. Małecki. 2020. Empirical Ecocriticism: Environmental Texts and Empirical Methods. ISLE: Interdisciplinary Studies in Literature and Environment 27: 327-36. [CrossRef]

Sedgwick, Eve Kosofsky. 2003. Touching Feeling. Affect, Pedagogy, Performativity. Durham and London: Duke University Press.

Serpell, C. Namwali. 2014. Seven Modes of Uncertainty. Cambridge: Harvard University Press.

Shklovsky, Viktor. 2017. Art as Technique. In Literary Theory: An Anthology. Edited by Julie Rivkin and Michael Ryan. Chichester: Wiley Blackwell, pp. 8-14. First published in 1916.

Smidt, Jon. 2018. Norskfaget Mellom Fortid og Framtid: Scene og Offentlighet. Bergen: Fagbokforlaget.

Sommer, Doris. 2014. The Work of Art in the World. Durham and London: Duke University Press.

Sønneland, Margrethe. 2019. Friction in Fiction. A Study of the Importance of Open Problems for Literary Conversations. L1-Educational Studies in Language and Literature 19: 1-28. [CrossRef]

Thavenius, Jan. 2004. Den radikala estetiken. In Skolan Och Den Radikala Estetiken. Edited by Lena Aulin-Gråhamn, Magnus Persson and Jan Thavenius. Lund: Studentlitteratur, pp. 97-124.

UNESCO. 2017. Education for Sustainable Development Goals: Learning Objectives. Paris: United Nations Educational, Scientific and Cultural Organization.

Utdanningsdirektoratet. 2019. Core Curriculum: Sustainable Development. Available online: https://www.udir.no/lk20/overordnet-del/prinsipper-for-laring-utvikling-og-danning/tverrfagligetemaer/2.5.3-barekraftig-utvikling/?lang=eng (accessed on 30 November 2020).

Wei, Liwei, P. Karen Murphy, and Carla M Firetto. 2018. How Can Teachers Facilitate Productive Small-Group Talk? An Integrated Taxonomy of Teacher Discourse Moves. The Elementary School Journal 118: 578-609. [CrossRef]

Wertsch, James V. 1991. Voices of the Mind: A Sociocultural Approach to Mediated Action. Cambridge: Harvard University Press.

Wiek, Arnim, Lauren Withycombe, and Charles L Redman. 2011. Key Competencies in Sustainability: A Reference Framework for Academic Program Development. Sustainability Science 6: 203-18. [CrossRef]

Publisher's Note: MDPI stays neutral with regard to jurisdictional claims in published maps and institutional affiliations.

(C) 2020 by the author. Licensee MDPI, Basel, Switzerland. This article is an open access article distributed under the terms and conditions of the Creative Commons Attribution (CC BY) license (http://creativecommons.org/licenses/by/4.0/). 